Krzysztof Butryn*

\title{
An Analysis of Arrangements of the Local Spatial Management Plans in the Context \\ of Determining Coverage of Transmission Easements - the Example of the City of Krakow**
}

\section{Introduction}

One of the most important problems connected with establishing the transmission easement is determining its spatial extent - area of the transmission easement zone. This is due to the fact that the area is the basis for calculating the remuneration for the establishment of transmission easement and to determine compensation for non-contractual use of the property by the transmission entrepreneur [3].

Determination of the transmission easement zone area, however, is a matter of a number of concerns, and this is due to the fact that in Polish legislation, there are no records of the methodology for determining the spatial extent of transmission easement ${ }^{1}$.

One approach, frequently encountered in practice, used both by individual surveyors, court experts in the field of geodesy and cartography, as well as recognized in the jurisprudence of courts of general jurisdiction, involves calling upon the arrangements of local spatial management plans (or Conditions of Development and Spatial Management decision). Cited local law often contains specific arrangements for the areas of transmission equipment influence on adjacent land. The municipality has, therefore, a serious tool that enables the formulation of planning poli$\mathrm{cy}$, through the establishment of zones of transmission equipment influence, independently of transmission entrepreneurs [2].

As part of this work, there was carried out an analysis of the arrangements of all obligatory local spatial management plans in the area of Krakow city, in the context of transmission equipment.

First, the analysis covered the current state of planning in Krakow and the status of ongoing work on plans drawn up. Then, the analysis covered the texts of the

* AGH University of Science and Technology, Faculty of Mining Surveying and Environ-mental Engineering, Krakow, Poland

** Funded by a dean's grant number 15.11.150.408/16

1 According to the current legal status as of June 1, 2016 year. 
resolutions and the drawing parts of all obligatory local spatial management plans. Based on the author's proposed form, there was made the evaluation of the scope of the findings of each local plan, taking into account the provisions for five different types of transmission networks: energy, water, sewage, gas and heating. Finally, there is presented a practical example of determining the range of transmission easement zone, based on one of the obligatory local spatial management plans.

The collected and analyzed data made it possible to draw conclusions regarding the planning policy of the city of Krakow, in the context of the establishment of protection zones around transmission facilities, in relation to particular types of technical infrastructure (utilities). Practical considerations are preceded by a synthetic theoretical introduction.

\section{Types of Land Areas Associated with Transmission Devices}

In the process of establishing a transmission easement, there can be distinguished different types of land areas associated with the transmission facilities location. It should be noted, that the type of area is connected with the phase of the implementation and operation of the transmission equipment. The systematics of these stages is synthetically presented by KSWS 4 standard [3] (Fig. 1).

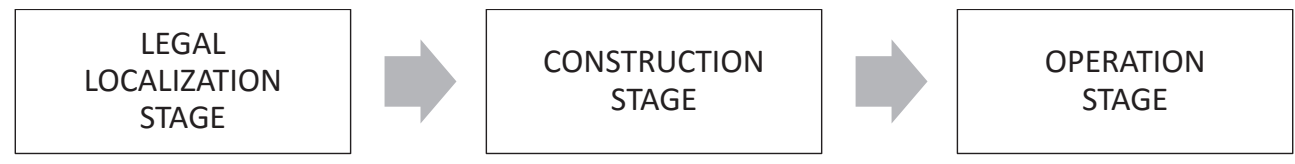

Fig. 1. Stages of implementation and operation of transmission facilities

Source: own studies based on [3]

At the stage of the legal localization of the device, it is placed in a local spatial management plan or in a Conditions of Development and Spatial Management decision. As a result, the damage due to location occurs, in accordance with art. 36 par. 1 of the Spatial Planning and Management Act of March 27, 2003. As part of the construction stage, there is performed a physical foundation of equipment on the property. The operation stage is the time interval in which the transmission entrepreneur shares the servient estate, in order to correct the use of the pre-built device.

As rightly observes Sajnóg [4], at various stages of the investment, the transmission devices are surrounded by different, as to its nature, areas (zones) (Fig. 2).

According to arrangements of the Construction law, the influence area of an object is an area designated in the vicinity of a building on the basis of separate regulations, introducing the related object restrictions on land use of the area. This is an area of the property, within which the ownership is limited to ensure proper and, above all, safe operation of the equipment and the safety of people and property. 
To determine the extent of the impact area of the device may be relevant particular strips of land along linear or cubic objects, established at the stage of the legal location of the device. At the same time, areas described in the applicable laws, standards and technical guidance should be also taken into account. In practice, the area of influence of the object is identified with the area described in local spatial management plan, and in the absence of a plan - in a Conditions of Development and Spatial Management decision.

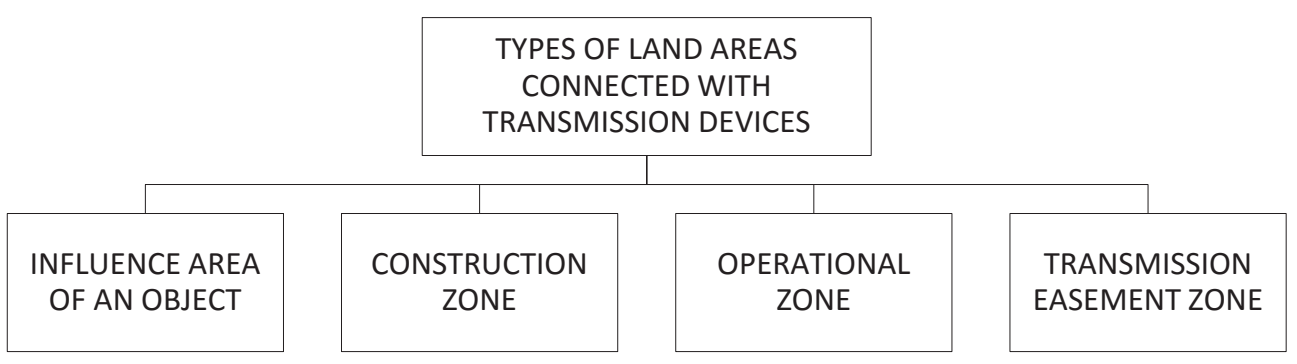

Fig. 2. Types of land areas connected with transmission devices

Source: own studies based on [4]

The second specified area is the construction zone, called also the work zone or assembly zone. It is established only for the duration of the infrastructure construction and its geometric attributes are included in the building project [4]. Within the construction zone may arise damage to the component parts of the property and benefits of the property.

The operational zone is associated with a real estate necessary for use by the operator of the transmission equipment [3]. Within this kind of zone, there are input significant restrictions on the use of the property, e.g. a ban on the construction of buildings or planting trees. The width of the operation zone primarily depends on the technical parameters of a specific device of the transmission.

The last, and the most important in the context of this study, is the transmission easement zone. According to current legislation, the methodology for determining the spatial extent of transmission easement is not regulated by law. Nevertheless, in accordance with an article $305^{1}$ of the Civil Code, the burden of real estate easement transmission must be in accordance with the intended use of obligatory equipment in the space. The spatial range of easement should be determined in each case depending on the type and technical parameters of the device and in any case should include minimum operational zone. In certain circumstances, the transmission easement zone may include the previously described object influence area. Depending on the circumstances specified on legal localization, construction and operation stage, as well as determined property destination, the transmission easement zone may further comprise the zone of the device and other parts of the property, which has lost in whole or in part the importance for holding title to real estate in the 
context of using it for its intended purpose. The approach of setting a transmission easement zone as identical with the area of influence of the object, defined in the local spatial management plan, is often implemented in practice, used by both individual surveyors and court experts in the field of geodesy and cartography.

\section{City of Krakow - State of Local Spatial Management Planning (Fig. 3)}

According to art. 154 of Real Estate Management Act of August 21, 1997, purpose of real estate is determined on the basis of the local spatial management plan. The figure below shows the current status of a planning in the city of Krakow - the obligatory plans, enacted and waiting for entry into force, as well as prepared. According to the current state at the time of development (Fig. 3), the area of Krakow has 137 local spatial management plans in force. These include the range of a total of $48.2 \%$ of the city area. Currently there is no local plan adopted, which is waiting for entry into force. There are being developed 64 local spatial management plans, which spatial extent substantially coincides with the plans currently in force.

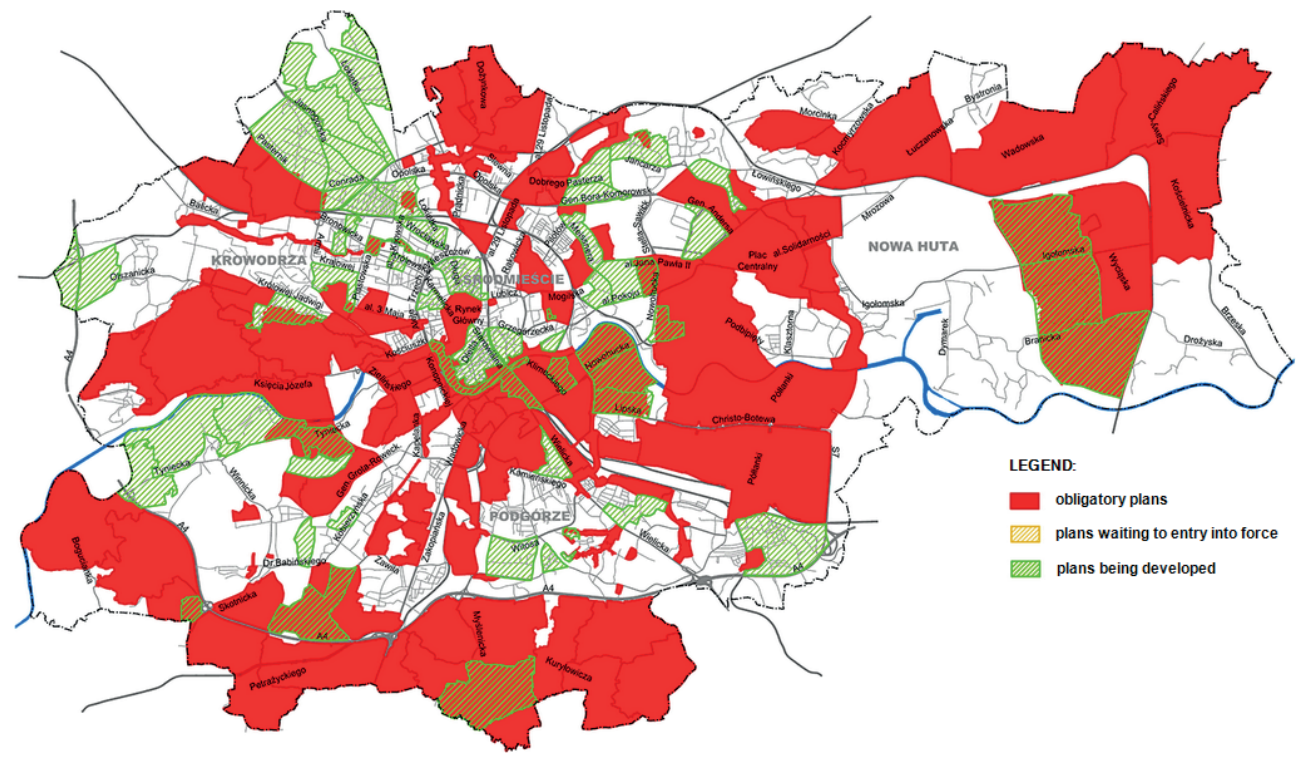

Fig. 3. City of Krakow - state of a local spatial management plans (the condition actual on 1 June 2016)

Source: http://planowanie.um.krakow.pl/, own studies

It should be noted that since the entry into force of the Spatial Planning and Management Act of March 27, 2003, the number of obligatory plans in Krakow is 
steadily increasing, especially in the past five years (from 2011), this coverage has increased from $36 \%$ to over $48 \%$ (according to GUS). However, that is still more than half of the city is devoid of the obligatory plan, which makes these areas a number of significant restrictions on the real estate management [2].

\section{Description of the Study}

The study involved 134 local spatial management plans (other three acts represent local changes that do not concern the substance of the issues examined). There were analyzed the findings contained in the resolutions, as well in drawing parts of local plans.

First of all, plans were divided into ones that are obligatory from the date before 3 August 2008, the day of appearance in Polish legislation the institution of transmission easement, and acts which are in power from the date after this day. It was found that 102 local spatial management plans, which cover the area of almost 13000 hectares, came into force, while in the Polish legislation functioned the term of transmission easement. The remaining 32 plans, with a range of less than 3000 hectares, began their validity before 3 August 2008. It follows that the vast majority of local spatial management plans resolutions was a time when it was possible to establish a transmission easement.

Then, based on the author's proposed simplified form, it was made to assess the extent of any arrangements with local plans, taking into account the provisions for five different types of transmission networks: energy, water supply, sewerage, gas and heating.

For each type of network, the parameters set by the plan were analyzed by selecting one or more of the following options (note - in individual plans are found different names for areas of impact transmission devices, for simplicity assumed one name - the area of influence):

- protection zone - the range specified in the plan, independent of network parameters (fulfilled if the local spatial management plan defines a protection zone around the transmission units, which width is independent of the technical parameters of the network);

- protection zone - the range specified in the plan, dependent on network parameters (fulfilled if the local spatial management plan defines a protection zone around the transmission units, which width is dependent on the technical parameters of the network);

- protection zone - dependent on other plan arrangements (fulfilled if the local spatial management plan defines a protection zone around the transmission units, dependent on other arrangements plan, like different widths for various purposes e.g. imposes distance from other objects - for example the need to offset the building $5 \mathrm{~m}$, and vegetation for $1 \mathrm{~m}$ ); 
- protection zone - reference to separate/industrial regulations (fulfilled when the local spatial management plan, admittedly indicates the existence of the protection zone, however, in order to determine the geometrical parameters refers to separate regulations, in particular industrial ones);

- other (fulfilled if the local plan indicates the formation of the buffer zone, but the proposed solution cannot be recognized in any of the categories above, including an appeal to the breadth of the zone);

- lack of arrangements (on the area covered by the local plan there are technical infrastructure, local spatial management plan marks their existence, but does not provide any findings regarding the impact areas)

- not applicable (fulfilled when the local spatial management plan does not refer at all to the protection zones associated with the transmission devices and does not exclude the existence of transmission facilities in the area covered by the local plan).

Among the analyzed 134 local spatial management plans, 26 refer to all five types of network utilities. Forty-one plans do not provide regulations relating to at least one type of network. Of course, the lack of arrangements for specific types of equipment does not exclude their foundation within areas covered by the local plan.

\section{Energy Networks (Fig. 4)}

Arrangements for areas around energy networks were included on pages of 67 of the currently obligatory local spatial plans. This means that exactly $50 \%$ of local plans apply to them.

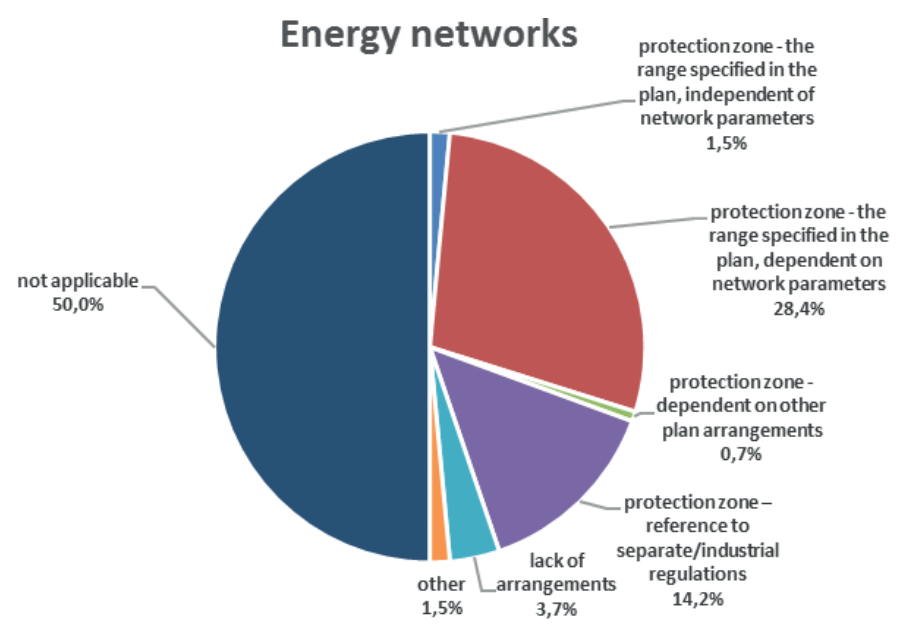

Fig. 4. The findings of the local spatial management plans from the Krakow area on energy networks 
Among the plans which regulate the arrangements for energy networks, by far the most of them (28.4\% of all plans) proposes the establishment of protection zones and at the same time gives a particular extent of any such zone varied due to the parameters of the network. Nearly less than half (14.2\% of all plans) among all the plans proposes to establish a protection zone and recommend to seek the arrangements for the width of the zones in separate provisions, in particular the industrial ones (especially for high voltage lines). Five plans (3.7\% of the population) have in its area power grids that can be covered by the easement of transmission, but does not refer to the issue of the protection zone. Two plans offer width of protection zones independent from the network parameters. Two other suggested identifying transmission easement zones as the same with operational zone. Only the one local plan correlates the width of the buffer zone with the other arrangements of the plan.

\section{Water Supply (Fig. 5)}

Arrangements for the zones around water supply networks were included in $49.3 \%$ (66 acts) of the currently applicable plans.

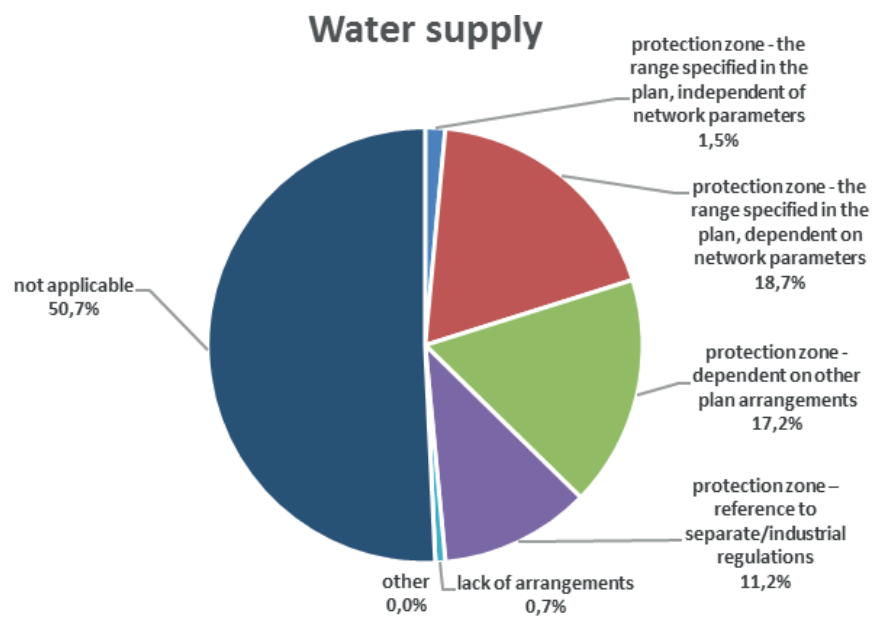

Fig. 5. The findings of the local spatial management plans from the Krakow area on water supply networks

Among the plans to regulate the arrangements for water supply, most of them $(18.7 \%$ of all plans) propose the establishment of protection zones and at the same time gives a particular extent of any such zone varied due to the parameters of the network. Slightly less (17.2\% of all plans) plan proposes the establishment of a protection zone dependent on other arrangements of plan e.g. based on the distance to objects of different types (buildings, woodlots). Slightly more than $11 \%$ of 
all the local spatial management plans suggests establishing protection zones referring to the arrangements of separate regulations (in particular industrial). Two plans give numerical values of the width of protection zones independent from the network parameters. One plan notes the existence of equipment on its territory, but does not specify the arrangements to the protection zones.

\section{Sewerage (Fig. 6)}

Arrangements for the areas around the sewer networks were included in the $44.0 \%$ of the currently obligatory local zoning plans (59 acts).

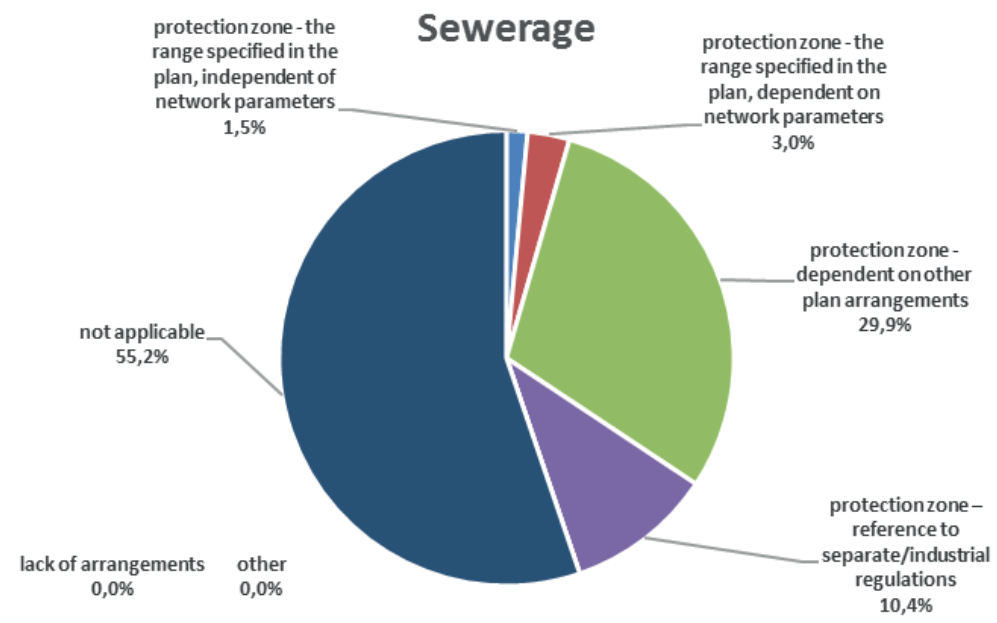

Fig. 6. The findings of the local spatial management plans from the Krakow area on sewerage networks

Among the plans containing arrangements for sewerage systems, most of them (29.9\% of the total) proposes to establish a protection zone dependent on other plan arrangements, e.g. based on the distance to objects of different types (buildings, woodlots). Slightly more than $10 \%$ of all the local spatial management plans suggests relating to the findings of separate regulations (in particular industrial ones). Four local plans propose to establish the parameters of the protection zones on the basis of the technical parameters of the particular network, while the other two declare a protection zone independent from the technical parameters of the network.

\section{Gas Pipelines (Fig. 7)}

Arrangements for the areas around the gas networks are contained in nearly $51 \%$ of the currently applicable local spatial management plans (68 acts). Among the 
plans that regulate the arrangements for gas networks, most of them $(42.5 \%$ of the total) propose to establish a protection zone in reference to the separate regulations.

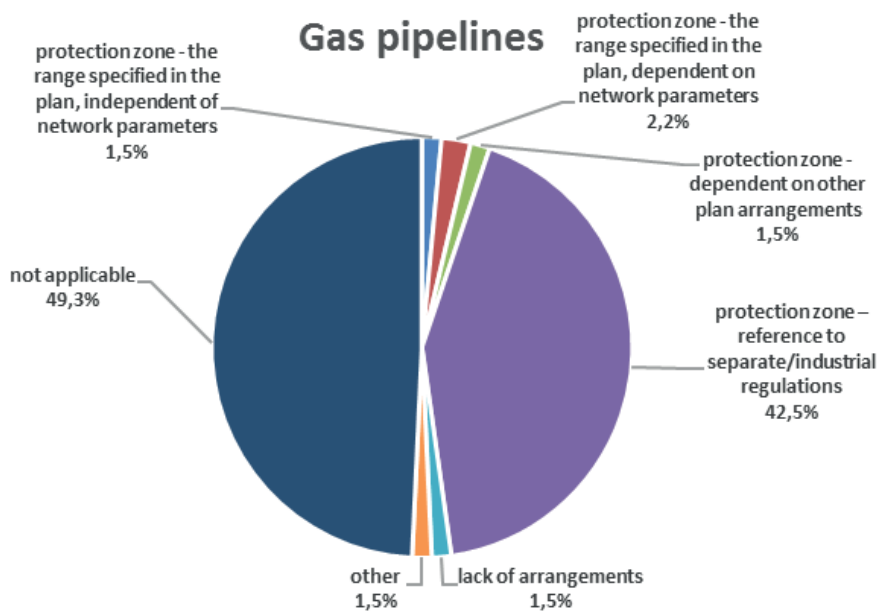

Fig. 7. The findings of the local spatial management plans from the Krakow area on gas networks

This is due to the necessity of determining for gas networks so called control zones, which should be set for the entire period of their use (cf. Regulation of the Minister of Economy on 26 April 2013. on the technical conditions to be met by gas networks and their location). Three of the 134 surveyed local spatial management plans propose the geometric parameters of the protection zones vary due to the technical parameters of the network. The remaining four findings refer to a total of eight local plans, two for each. Two of them offer the protection zone dimensions independent of the technical parameters of the network, the two provide a protection zone depending on other arrangements the plan, the two suggest the identification of the protection zone with an operational zone, while the other two do not provide any solution.

\section{Heating (Fig. 8)}

Arrangements for the areas around the heating networks were included in the $27.6 \%$ of the currently applicable local zoning plans (37 acts), least of all types concerned network, which is justified by the fact that the urban heating network is the least-developed network in Krakow (from those listed). Among the plans that regulate the arrangements for the heating networks by far the most $(14.2 \%$ of all plans in force) gives the size of the protection zone depends on the technical parameters of the network. 


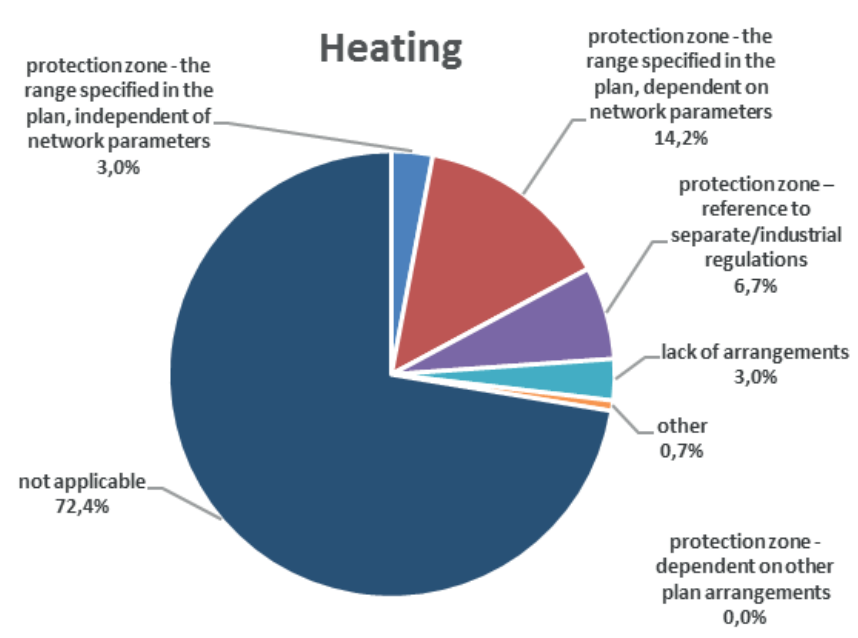

Fig. 8. The findings of the local spatial management plans from the Krakow area on heating networks

Nearly $7 \%$ of local spatial management plans suggests the establishment of a protection zone in reference to the findings of separate regulations. Four plans declare the extent of zones independent of the network parameters, four refrain from the findings in this matter, in spite of the possibilities or location in their area of heat transmission equipment. Only one contains the suggestion that coverage of the protection zone should be identified with the operational zone.

\section{Empirical Example}

Below there is an example showing the mechanism for determining the impact area of transmission equipment (based on local zoning plan of "Myśliwska" area) (Fig. 9).

Red arrow means the geometric center of the main line heat $2 \times \varnothing 800 \mathrm{~mm}$, while the blue one means operational zone. Total width of the zone is operating approximately about 3.2 meters. But according to the provisions of the resolution:

“9) determine the technical areas along heating lines, which prohibits the location of buildings:

a) $5.0 \mathrm{~m}$ for heating lines with a diameter greater than $2 \times ø 500$,

b) $3.0 \mathrm{~m}$ for heating lines with a diameter $2 \times \emptyset 200-500$,

c) $2.0 \mathrm{~m}$ for heating lines with a diameter of less than $2 \times ø 150^{\prime \prime}$

Accordingly, in determining the range of transmission easement zone it is reasonable to determine it extended on both sides up to 5 meters. 


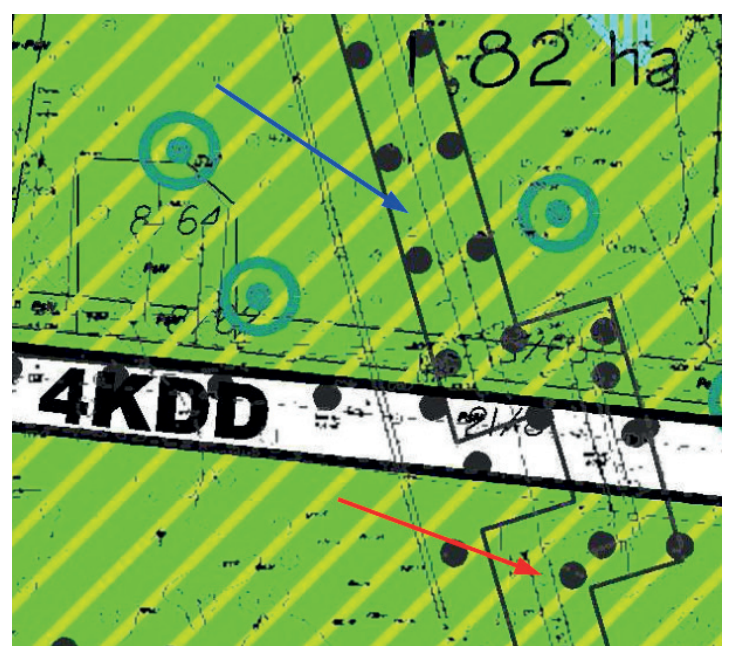

Fig. 9. Fragment of the obligatory local spatial management plan of area "Myśliwska"

Source: http://planowanie.um.krakow.pl/, own studies

\section{Summary}

Due to the lack of statutory regulation, the term of transmission easement zone is an important issue from a practical point of view. One of the approaches used in determining the spatial coverage of transmission easement is a reference to arrangements of the local spatial management plan. The local plan often includes specific arrangements for the areas of influence of transmission equipment on adjacent land. This study analyzed the arrangements of the obligatory local spatial management plans in the city of Krakow, in the context of provisions relating to the impact zones of transmission equipment.

For each type of network utilities, there can be observed characteristic trends shaping the areas of influence of transmission equipment. In the case of electricity networks, water supply and heating, the most commonly used approach is to define the protection zone depending on the technical parameters of a particular network. In the case of sewer networks, prevails proposal to establish a protective zone dependent on other arrangements of such plan, e.g. based on the distance to objects of different types and basic purpose of land. For gas networks, the most frequently chosen direction is to establish a protection zone in reference to the separate regulations. This is due to the necessity of determining for gas networks so called - control zones, which should be set for the entire period of their use.

With the increasing coverage of the city by local spatial management plans, there is expected to increase the number of solutions regulating the geometric parameters of the impact areas of transmission equipment. 
An overview of planning documents in the Krakow area, shows that the for the areas of the transmission facilities location, which may affect the environment, a local spatial management plan usually sets range of impact area of the object, which can be taken into account when legislating transmission easement. At the same time plans cover less than half the area of the city, among them an average of only about half relates to the subject matter, which causes that in most parts of the city there are no arrangements from local spatial management plans concerning protective zones around transmission equipment.

\section{References}

[1] Bochaczyk J.: Stużebność przesyłu jako szczególny przypadek ograniczenia praw do nieruchomości. AGH, Kraków 2015 [M.Sc. thesis, supervisor: E. Preweda].

[2] Butryn K., Preweda E.: Selected Issues of Establishing and Functioning of the Transmission Easement. Geomatics and Environmental Engineering 2016, vol. 10, no. 1.

[3] Powszechne Krajowe Zasady Wyceny - Krajowy Standard Wyceny Specjalistyczny 4: Określanie wartości stużebności przesyłu oraz wynagrodzenia za bezumowne korzystanie z nieruchomości przez przedsiębiorców przesyłowych. Polska Federacja Stowarzyszeń Rzeczoznawców Majątkowych, 2014.

[4] Sajnóg N.: Infrastruktura techniczna związana z przesyłem i dystrybucja mediów oraz towarzyszace jej pasy terenów. Infrastruktura i Ekologia Terenów Wiejskich, nr 2014/II, 2014, pp. 467-480.

[5] Ustawa z dnia 21 sierpnia 1997 r. o gospodarce nieruchomościami. Dz.U. 1997 nr 115, poz. 741 z późniejszymi zmianami; tekst jednolity: Dz.U. 2015, poz. 1774 [Journal of Laws 1997, no. 115, item 741 with amendments; consolidated text: Journal of Laws 2015, item 1774].

[6] Ustawa z dnia 23 kwietnia 1964 r. - Kodeks cywilny. Dz.U. 1964, nr 16, poz. 93 z późniejszymi zmianami, tekst jednolity: Dz.U. 2014 z późniejszymi zmianami [Journal of Laws 1964, no. 16, item 93 with amendments; consolidated text: Journal of Laws 2014 with amendments].

[7] Ustawa z dnia 27 marca 2003 r. o planowaniu i zagospodarowaniu przestrzennym. Dz.U 2003, nr 80, poz. 717 z późniejszymi zmianami [Journal of Laws 2003, no. 80 , item 717 with amendments].

[8] Zamroch P.: Problematyka prawna urzadzeń przesyłowych na tle orzecznictwa Sądu Najwyższego i sądów powszechnych. [in:] Dąbek J., Nowakowska M., Zamroch P., Wybrane zagadnienia wyceny nieruchomości a problematyka prawna, ekonomiczna i przestrzenna zwiazana z infrastruktura techniczna, wyd. 2 poprawione, Polska Federacja Stowarzyszeń Rzeczoznawców Majątkowych, Warszawa 2015. 